\title{
Effect of Fungicide Treatments and Sanitation Practices on Brown Rot Blossom Blight Incidence, Phytotoxicity, and Yield for Organic Sour Cherry Production
}

\author{
I. J. Holb, Department of Plant Protection, University of Debrecen, Centre of Agricultural Sciences P.O. Box 36, H- \\ 4015 Debrecen, Hungary; and G. Schnabel, Department of Entomology, Soils, and Plant Sciences, Clemson Univer- \\ sity, Clemson, SC 29634
}

\begin{abstract}
Holb, I. J., and Schnabel, G. 2005. Effect of fungicide treatments and sanitation practices on brown rot blossom blight incidence, phytotoxicity, and yield for organic sour cherry production. Plant Dis. 89:1164-1170.

Demand for organically grown fruit, including sour cherry, is rising in Europe and the United States, but the limited tools for disease management have not been thoroughly investigated. In this study, management of brown rot blossom blight, caused by Monilinia laxa, was examined for organic sour cherry production in Hungary. Combinations of sanitation practices and fungicide treatments, including copper hydroxide, lime sulfur, and micronized and nonmicronized wettable sulfur, were investigated in 2 years and two cultivars. The effect of fungicide treatments on yield and phytotoxicity on spur-leaf clusters was also determined. Among fungicide treatments suitable for organic production, copper hydroxide and lime sulfur alone or in combination with micronized wettable sulfur were most effective for blossom blight control when applied twice (at closed blossom and full bloom) or three times (at closed blossom, full bloom, and petal fall) during bloom. Both treatments were not as effective as the conventional standard and caused more damage on spur-leaf clusters during wet weather conditions, but significantly increased crop yield compared with the untreated control or wettable sulfur treatments. Micronized and nonmicronized sulfur applied up to three times during bloom were equally effective, did not impact yield, were not phytotoxic, and reduced blossom blight compared with the untreated control. Sanitation (the removal of blighted twigs and mummified fruit) reduced blossom blight in both cultivars compared with nonsanitized plots when disease pressure was high. The need for an integrated approach to effectively manage blossom blight in organic sour cherry production is discussed. This is the first in-depth characterization of cultural and chemical brown rot blossom blight control options for organic sour cherry production.
\end{abstract}

Additional keywords: brown rot incidence, Érdi bőtermő, IFOAM, Prunus vulgaris, Újfehértói fürtös

Brown rot blossom blight, caused by Monilinia laxa (Aderhold \& Ruhland) Honey, is a devastating disease of sour cherry (Prunus vulgaris Mill.). The disease is endemic in Europe $(47,57)$ and also causes epidemics in stone fruit orchards on the West Coast and in the Midwest of the United States $(7,9,36)$. In rainy springs, blossom blight causes severe crop losses in sour cherry orchards in Hungary $(20,44)$. Depending on weather conditions, blossom blight can be controlled with one to three applications of protectant or systemic fungicides during the bloom period in conventionally grown stone fruit orchards $(21,36,37)$.

Corresponding author: I. J. Holb

E-mail: holb@agr.unideb.hu

This work was partly supported by the Hungarian Scientific Research Fund (OTKA F043503) and a János Bolyai Research Fellowship awarded to I. J. Holb.

Accepted for publication 6 June 2005.

DOI: 10.1094/PD-89-1164

(C) 2005 The American Phytopathological Society
Concerns about pesticide residues have generated increased interest in organically grown fruit $(22,39,49)$. The International Federation of Organic Agriculture Movements (IFOAM) and, recently, the United States Department of Agriculture through the National Organic Program (NOP) fully implemented their standards for organic crop production, outlining the criteria that must be met to label agricultural products as "organic" (25-27). In contrast to conventional fruit production, only natural products, such as farmyard manure, compost, soluble rock powder, copper and sulfur-based products, botanical soaps, botanical insecticides, sanitation practices, and biological products are permitted in organic fruit production (25-27). From these options, copper-based products, elemental and lime sulfur, and sanitation practices are likely to be most effective for blossom blight control.

Copper-based products have been used since the beginning of the twentieth century for blossom blight control of apricot and sour cherry $(8,42)$. Applications of Bordeaux mixture were recommended at pre-bloom, and two additional applications at full bloom and post-bloom, if disease pressure was high. Cumulative applications of Bordeaux mixture were phytotoxic to blossoms, however $(8,42)$. Nowadays, in most commercial Hungarian sour cherry orchards, one to three applications of copper hydroxide $(0.07$ to $0.2 \%)$ are applied in the spring between dormant and white flower bud stages (21).

In Europe, copper levels of some agricultural soils exceed the Dutch limit (2) of $36 \mathrm{mg} / \mathrm{kg}$ of soil following prolonged use of copper-based products $(14,38,55)$. Copper-polluted orchards from Europe were shown to negatively impact soil ecology and to have detrimental effects on earthworm populations $(15,24,38,55)$. Already, some European countries (e.g., the Netherlands and Scandinavian countries) have banned copper-based products (49) and other European countries likely will follow suit (23). Hence, there is an urgent need for replacements of copper-based products in European agriculture, including organic fruit production.

Elemental sulfur fungicide long has been used for plant disease control, including blossom blight; however, its efficacy undoubtedly is lower than that of modern, conventional fungicides $(9,13,29,56,57)$. In Hungarian organic cherry, peach, and apricot production, three applications of elemental sulfur are recommended for blossom blight control, similar to recommendations in other regions $(1,31,48)$. Elemental sulfur commonly is formulated as a wettable powder, which can successfully protect peaches from brown rot when disease incidence is low or moderate $(10,43,58)$. Elemental sulfur also is available in a micronized wettable form, which is prepared by a special manufacturing process to ensure that particles are extremely fine (53). Efficacy tests indicated that micronized wettable sulfur may provide more effective control of peach scab $(41,43)$ than nonmicronized wettable sulfur. However, Schnabel and Layne (43) emphasized that the proposed superior effectiveness of micronized wettable sulfur compared with wettable sulfur against brown rot remains to be elucidated.

Lime sulfur is one of the oldest fungicides used in agriculture and may represent a viable alternative to copper fungicides. The common formulation contains a mixture of $29 \%(\mathrm{wt} / \mathrm{vol})$ calcium polysulphide and a small amount of calcium thiosul- 
phate (30). In early studies, its efficacy was reported to be similar to copper-based fungicides, but it also caused cumulative phytotoxicity $(16,18,34)$. More recent research showed that lime sulfur may be able to replace copper-based products in organic apple production based on its efficacy against scab $(22,51,52)$. However, no detailed study is available on the efficacy or phytotoxicity of lime sulfur in organic sour cherry production.

Sanitation (i.e., removal of blighted twigs and mummified fruit) is widely recommended against all brown rot diseases of fruit crops $(9,28,49,54,57)$; however, its impact on disease epidemics is dependent upon weather conditions and cultivar susceptibility to brown rot $(7,9,49)$. The effect of sanitation on blossom blight has not been evaluated alone or in combination with sulfur or copper-based products on different cultivars in organic sour cherry orchards.

The objective of this 2-year study was to compare the effectiveness and phytotoxicity of copper hydroxide, lime sulfur, and micronized and nonmicronized wettable sulfur treatments for blossom blight control in organic sour cherry production. Treatments were evaluated on two sour cherry cultivars and separate orchard plots with and without sanitation. The effect of fungicide treatments on yield also was determined.

\section{MATERIALS AND METHODS}

Orchard and plant material. The study was conducted in an organic sour cherry orchard at Eperjeske (Hungary), located at $47^{\circ} 31^{\prime} 60^{\prime \prime} \mathrm{N}$ and $21^{\circ} 37^{\prime} 60^{\prime \prime} \mathrm{E}$, during 2003 and 2004. The experimental orchard (5.8 ha) consisted of 19 rows with a distance between rows of $6 \mathrm{~m}$ and between trees within a row of $4 \mathrm{~m}$. The orchard was planted in 1997 with three selffertile sour cherry cultivars: eight rows of cv. Újfehértói fürtös and of cv. Érdi bötermő and three rows of cv. Érdi jubileum. Cultivars were grafted on Prunus mahaleb rootstock. Trees have been grown according to the Hungarian organic production guidelines (3) derived from IFOAM standards (25-27). The guidelines have been applied since planting of the orchard in 1997. The orchard soil type was brown forest soil with alternating layers of clay substance. Trees were approximately 3 to $3.5 \mathrm{~m}$ tall during the 2-year assessment period. Intrarow spacing between branches in the crown of adjacent trees was approximately 0.1 to $0.3 \mathrm{~m}$ and between adjacent rows was approximately $2.6 \mathrm{~m}$. A $0.5-\mathrm{m}$-wide strip of bare soil was maintained in the rows and grass was grown in the spacings between rows. The orchard was not irrigated. Treatments and observations were made on cvs. Érdi bőtermő and Újfehértói fürtös. Both cultivars are susceptible to blossom blight, but cv. Érdi bötermő is considered to be more susceptible than cv. Újfehértói fürtös (44). Cultivars Érdi bötermö and Újfehértói fürtös belong to the early- and lateblooming groups, respectively (35), and their fruit maturity dates range from 13 to 22 June and from 5 to 12 July, respectively (45).

Environmental monitoring. Rainfall (millimeters day ${ }^{-1}$ ) and mean daily temperature $\left({ }^{\circ} \mathrm{C}\right.$ day $\left.^{-1}\right)$ were recorded during the test periods in 2003 and 2004 using a Metos Compact agrometeorological station (Pessl Instrument GmbH, Weiz, Austria).

Sanitation and fungicide treatments. Two sanitation treatment blocks were established for each cultivar in each year. In block 1, all blighted twigs and mummified fruit were removed; in block 2 , no sanitation practices were conducted. In the sanitized block, mummified fruit and twigs were removed from the trees by pruning and mummified fruit were removed from the orchard floor in order to avoid infection from the crop debris. Both blocks were set up in 2002 and the same plots were used for the same mechanical control treatments for each cultivar in 2003. Both blocks were replicated three times and each consisted of a minimum of 150 trees per cultivar. Treatment blocks were prepared on 15 August 2002 and 17 August 2003 according to Wormald (57), who stated that sanitation is more effective in late summer because dead twigs contrast more sharply with healthy foliage than during the dormant season.

Within each sanitation block, fungicide treatments were performed for both cultivars in the springs of 2003 and 2004. Each fungicide treatment was replicated five times (single tree replications). The whole experiment was set up as a split-strip-splitplot design (split [cultivar]-strip [year]split [sanitation]-plot [fungicide]) accord- ing to Gomez and Gomez (17). Fungicide treatments were (i) untreated control (Untreated); (ii) conventional fungicide (Conv.); (iii) copper hydroxide, reduced rates (CoHydr.); (iv) nonmicronized wettable sulfur (Wett-S); (v) micronized wettable sulfur (MWett-S); (vi) lime sulfur, reduced rates (Lime-S); and (vii) lime sulfur in combination with micronized wettable sulfur, reduced rates (Lime-S+MWett-S). Application rates and times are listed in Table 1. Applied products were Funguran-OH 50 WP (77\% copper hydroxide; Spiess-Urania Chemicals GmbH, Hamburg, Germany), Kumulus S (80\% wettable sulfur; BASF Hungaria Ltd., Budapest, Hungary), Microthiol Special (80\% micronized wettable sulfur; Elf Atochem Agri BV, France), Tiosol (29\% calcium polysulphide; Tiosol Ltd., Kistelek, Hungary), Ronilan DF (vinclozoline, 50\%; BASF Hungaria Ltd., Budapest, Hungary), and Topas 100 EC (penconazol, $100 \mathrm{~g} \mathrm{liter}^{-1}$; Syngenta Ltd., Budapest, Hungary). All sprays were applied with a handheld spray gun (EMPASS; Huneschans 183905 XL Veenendaal, The Netherlands) with a ceramic hollow cone at 1.1 to $1.2 \mathrm{MPa}$ with a volume of 1,000 liter ha ${ }^{-1}$. All treatments received $0.5 \%$ micronized wettable sulfur (Microthiol Special) at 7- to 16-day intervals, depending on weather conditions, after fruit set (BBCH 71) until the middle of July. Calcium polysulphide (Tiosol) was applied at $2 \%$ in early March and a final spray of $2 \%$ copper hydroxide (Funguran$\mathrm{OH} 50 \mathrm{WP}$ ) was applied in mid-August in all treatments in both years and cultivars.

Blossom blight assessment. For each treatment, year, and cultivar, disease assessment was based on the percentage of blighted twigs 2 weeks after the petal fall application. One hundred randomly selected twigs from each quadrant of a tree

Table 1. Application rates in percentage of active ingredient of fungicide treatments at various bloom stages of sour cherry

\begin{tabular}{lccc}
\hline & \multicolumn{3}{c}{ Bloom stages, BBCH } \\
\cline { 2 - 4 } Fungicide treatments $^{\mathbf{w}}$ & $\mathbf{5 9}$ (closed blossom) & $\mathbf{6 5}$ (full bloom) & $\mathbf{7 0}$ (petal fall) \\
\hline Conv. & $0.12 ; 0.03^{\mathrm{x}}$ & $0.12 ; 0.03^{\mathrm{x}}$ & $\ldots$ \\
Co-Hydr. $\mathrm{y}, \mathrm{z}$ & 0.6 & 0.03 & 0.05 \\
Wett-S & 0.75 & 0.4 & 0.6 \\
MWett-S & 0.75 & 0.4 & 0.6 \\
Lime-S & 1.5 & 1.0 & 1.1 \\
Lime-S+MWett-S $^{\mathrm{z}}$ & $1.5+0.3$ & $1.0+0.3$ & $1.1+0.3$ \\
\hline
\end{tabular}

${ }^{\mathrm{w}}$ Conv. = conventional fungicide, vinclozoline and penconazol (Ronilan DF and Topas $100 \mathrm{EC}$, respectively); Co-Hydr. = copper hydroxide (Funguran-OH $50 \mathrm{WP}$ ); Wett-S = nonmicronized wettable sulfur (Kumulus S); MWett-S = micronized wettable sulfur (Microthiol Special); Lime-S = lime sulfur (Tiosol); Lime-S+MWett-S = lime sulfur in combination with micronized wettable sulfur (Tiosol + Microthiol Special).

${ }^{x}$ Conventional fungicide treatment was made with vinclozoline $(0.12 \%)$ in 2003 and penconazol $(0.03 \%)$ in 2004.

y Copper hydroxide was selected from the copper compounds because, according to Richardson (40), compounds such as $\mathrm{Cu}_{2} \mathrm{O}, \mathrm{Cu}(\mathrm{OH})_{2}$, and $\mathrm{CuCl}_{2} \cdot 3 \mathrm{Cu}(\mathrm{OH})_{2}$ had greater protective value than $\mathrm{CuSO}_{4}$. Even though they are sparingly soluble, they provide sufficient soluble copper to be toxic to fungi without adversely affecting the host.

${ }^{z}$ The selection of reduced dosages for copper hydroxide and lime sulfur sprays were based on results of a previous experiment about the efficacy and phytotoxicity of copper hydroxide and lime sulfur sprays during the bloom period, obtained in 2002 in the same organic sour cherry orchard (I. J. Holb and F. Abonyi, unpublished). 
were examined for disease symptoms as described previously $(5,37)$. A blossom was considered to be diseased when the petals, calyx, and less than one-third of pedicel were necrotic (50). A twig without flower was considered to be diseased if a blighted leaf was present. Values from the quadrants were averaged to obtain the percentage of diseased twigs per tree.

Assessment of phytotoxicity and yield. Phytotoxicity observations were made on 50 spur-leaf clusters (including vegetative
A

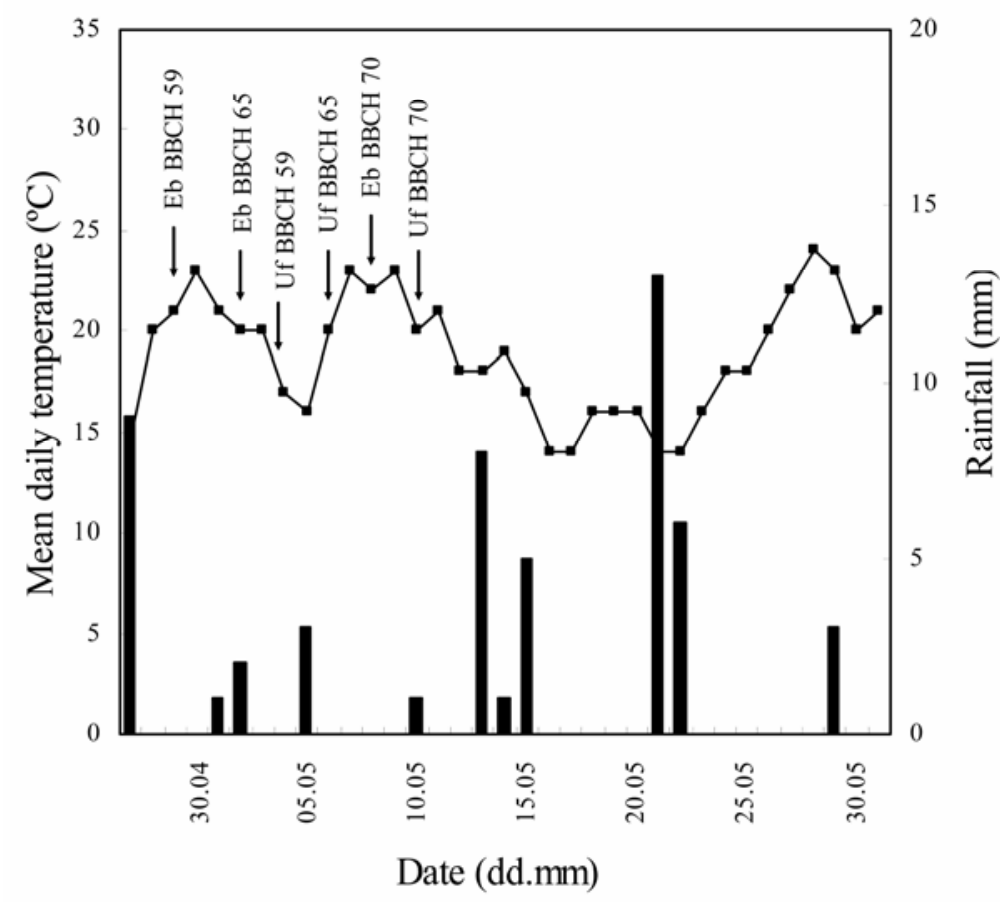

B

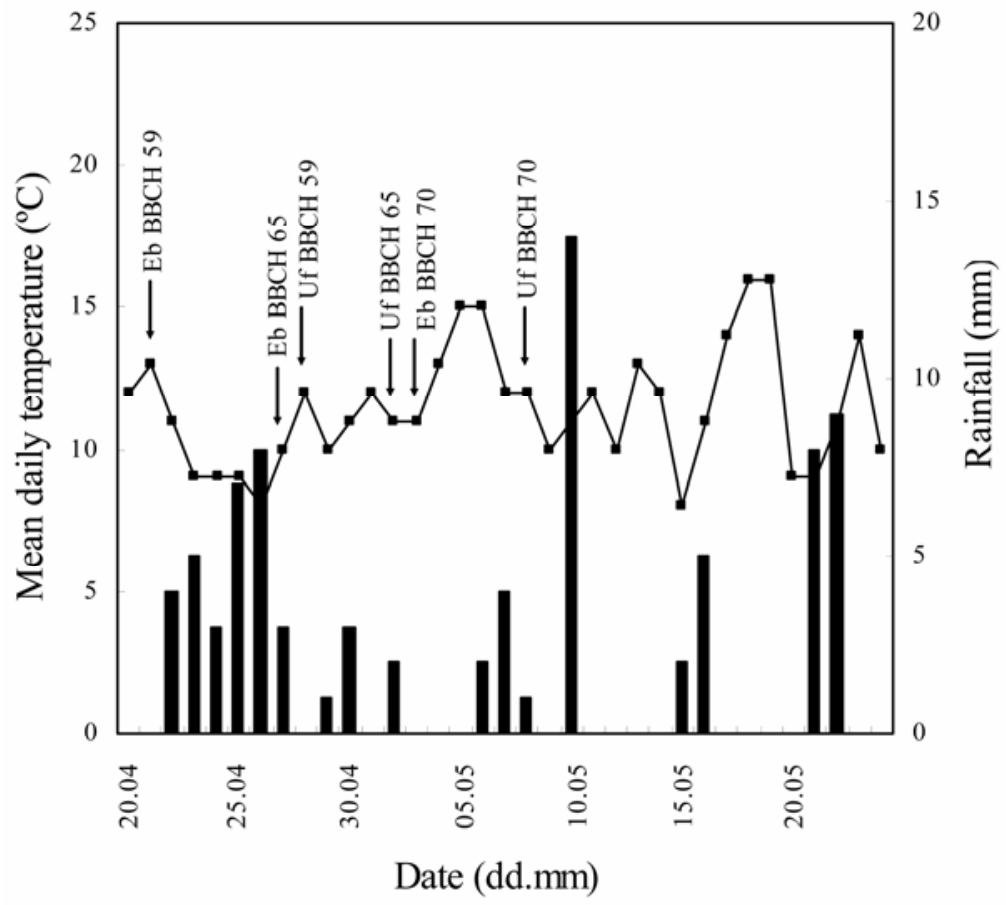

Fig. 1. Rainfall (bars), mean daily temperature (squares), and application timing of fungicide treatments (BBCH stages according to Meier et al. [32]) of cvs. Érdi bőtermő (Eb) and Újfehértói fürtös (Uf) during A, 2003 and B, 2004 in Eperjeske, Hungary. Bloom stages are BBCH $59=$ closed blossom, $\mathrm{BBCH} 65=$ full bloom, and $\mathrm{BBCH} 70=$ petal fall. and generative plant parts) per tree after 1 week of petal fall in both years, as described recently (4). Briefly, phytotoxicity assessments were rated according to the scale where $0=$ no damage; $1=$ cluster size 60 to $80 \%$ of normal size, no necroses on cluster; 2 = cluster size less than $60 \%$ of normal size, no necroses on cluster; $3=$ cluster size less than $60 \%$ of normal size and necroses on cluster less than $3 \% ; 4=$ cluster size less than $60 \%$ of normal size and 3 to $6 \%$ cluster necroses; and $5=$ cluster size less than $60 \%$ of normal size and necroses on cluster more than $6 \%$.

Yield was determined by the weight of all fruit per tree and treatment at harvest. Fruit yield was recorded on 15 and 20 June for cv. Érdi bötermö, and on 3 and 10 July for cv. Újfehértói fürtös in 2003 and 2004, respectively.

Statistical analyses. Blossom blight incidence and phytotoxicity data were transformed to angular $\left(Y=\operatorname{arcsine}[\%]^{1 / 2}\right)$ before analysis. No transformation was necessary for yield data. Blossom blight incidence, phytotoxicity, and yield data were analyzed by analysis of variance to evaluate the main effects of sanitation, fungicide treatment, cultivar, year, and their interactions. For blossom blight incidence, phytotoxicity, and yield data sets, significant $F$ tests $(P<0.05)$ were followed by a least significance difference (LSD) test for pairwise comparison of fungicide treatment means using $\mathrm{LSD}_{0.05}$ values. The effect of sanitation, cultivar, and year was analyzed separately before combining them (sanitation and cultivar and year). The effect of sanitation on phytotoxicity and yield was excluded from the analyses of pairwise comparison, because sanitation had no effect on phytotoxicity and yield. Standard errors of differences and degrees of freedom are given in the tables if appropriate. Genstat 5 statistical package (release 4.1; Lawes Agricultural Trust, IACR, Rothamsted, UK) was used for all analyses.

\section{RESULTS}

Environmental monitoring. Rainfall was 6 and $4 \mathrm{~mm}$ and mean daily temperature was 19.7 and $20.1^{\circ} \mathrm{C}$ during 8- and 7 day periods of bloom for cvs. Érdi bötermö and Újfehértói fürtös, respectively, in 2003 (Fig. 1A). In 2004, rainfall was 36 and 13 $\mathrm{mm}$ and mean daily temperature was 10.4 and $12.5^{\circ} \mathrm{C}$ during 13 - and 11-day periods of bloom for cvs. Érdi bőtermő and Újfehértói fürtös, respectively (Fig. 1B).

Blossom blight incidence. Analyses of variance on blossom blight incidence values (Table 2) indicated highly significant $(P<0.001)$ differences between years and cultivars. There was also a significant $(P<$ $0.05)$ difference in blossom blight incidence between the performance of the sanitation and the 22 fungicide treatments. There were significant year-cultivar, yearsanitation treatment, and year-fungicide 
treatment interactions; however, these were not as dominating as the main effect of cultivar or sanitation or fungicide treatment (Table 2).

The conventional fungicide treatment provided the best blossom blight control in each year, cultivar, and sanitation treatment (Table 3). Most copper- and sulfur-based fungicide treatments resulted in improved blossom blight control $(P<0.05)$ when applied two (at BBCH 59 and 65) or three times (at BBCH 59, 65, and 70) compared with one application at closed blossom or full bloom. Among inorganic fungicide treatments, the best control was achieved with copper hydroxide and lime sulfur treatments in each year, cultivar, and sanitation treatment. Copper hydroxide treatments, applied two or three times, did not differ significantly $(P<0.05)$ from the corresponding lime sulfur treatments. Lime sulfur treatments applied two or three times resulted in significantly lower blossom blight incidence only at $P<0.1$ compared with the corresponding wettable sulfur treatments. Blossom blight incidence in the micronized wettable sulfur treatments was not different from the corresponding nonmicronized wettable sulfur treatments in either year, cultivar, or sanitation treatment $(P<0.05)$. However, both wettable sulfur treatments, applied two or three times, controlled blossom blight significantly better $(P$ $<0.05)$ than the untreated control.

Blossom blight incidences generally were lower in the sanitation treatments

Table 2. Analysis of variance describing the effect of year, cultivar, sanitation, and fungicide treatments on brown rot blossom blight incidence (\%) caused by Monilinia laxa, phytotoxicity, and fruit yield in an organic sour cherry orchard (Eperjeske, Hungary, 2003 and 2004) ${ }^{\mathrm{z}}$

\begin{tabular}{|c|c|c|c|c|c|c|c|}
\hline \multirow[b]{2}{*}{ Source of variation } & \multirow[b]{2}{*}{ df } & \multicolumn{2}{|c|}{ Brown rot incidence } & \multicolumn{2}{|c|}{ Phytotoxicity } & \multicolumn{2}{|c|}{ Yield $\left(\mathrm{kg} \mathrm{tree}^{-1}\right)$} \\
\hline & & Mean squares & $P>F$ & Mean squares & $P>F$ & Mean squares & $P>F$ \\
\hline Year (Y) & 1 & $100,568.1$ & $<0.001$ & 27.2 & 0.002 & $1,333.8$ & $<0.001$ \\
\hline Cultivar (C) & 1 & $11,423.3$ & $<0.001$ & 2.2 & 0.037 & 79.4 & 0.002 \\
\hline Sanitation (S) & 1 & 910.8 & 0.035 & 0.2 & 0.479 & 1.1 & 0.211 \\
\hline Fungicide $(\mathrm{F})$ & 21 & $1,176.9$ & 0.022 & 47.5 & $<0.001$ & 22.5 & 0.024 \\
\hline $\mathrm{Y} \times \mathrm{C}$ & 1 & $1,354.1$ & 0.015 & 1.1 & 0.082 & 11.5 & 0.033 \\
\hline $\mathrm{Y} \times \mathrm{S}$ & 1 & 390.3 & 0.049 & 0.1 & 0.791 & 0.8 & 0.328 \\
\hline $\mathrm{Y} \times \mathrm{F}$ & 21 & 592.2 & 0.041 & 1.3 & 0.059 & 5.2 & 0.069 \\
\hline $\mathrm{C} \times \mathrm{S}$ & 1 & 37.5 & 0.335 & 0.1 & 0.811 & 0.3 & 0.867 \\
\hline $\mathrm{C} \times \mathrm{F}$ & 21 & 65.4 & 0.201 & 0.2 & 0.487 & 0.3 & 0.852 \\
\hline $\mathrm{S} \times \mathrm{F}$ & 21 & 14.3 & 0.492 & 0.5 & 0.123 & 0.2 & 0.953 \\
\hline $\mathrm{Y} \times \mathrm{C} \times \mathrm{S}$ & 1 & 60.2 & 0.178 & 0.3 & 0.323 & 0.7 & 0.331 \\
\hline $\mathrm{C} \times \mathrm{S} \times \mathrm{F}$ & 21 & 35.1 & 0.328 & 0.3 & 0.334 & 0.3 & 0.879 \\
\hline $\mathrm{Y} \times \mathrm{C} \times \mathrm{S} \times \mathrm{F}$ & 21 & 12.8 & 0.501 & 0.1 & 0.775 & 0.2 & 0.977 \\
\hline Residual & 745 & 4.4 & $\ldots$ & 0.3 & $\ldots$ & 0.2 & $\ldots$ \\
\hline Total & 878 & $\ldots$ & $\ldots$ & $\ldots$ & $\ldots$ & $\ldots$ & $\ldots$ \\
\hline
\end{tabular}

${ }^{\mathrm{z}} \mathrm{df}=$ Degree of freedom and $P>F=$ the significant probability values associated with the $F$ tests.

Table 3. Influence of sanitation and fungicide treatments on brown rot blossom blight incidence (\%) caused by Monilinia laxa in sour cherry cvs. Érdi bötermő and Újfehértói fürtös (Eperjeske, Hungary, 2003 and 2004) ${ }^{\mathrm{w}}$

\begin{tabular}{|c|c|c|c|c|c|c|c|c|c|}
\hline \multirow[b]{3}{*}{ Treatments $^{\mathrm{x}}$} & \multirow[b]{3}{*}{ Timing ${ }^{y}$} & \multicolumn{4}{|c|}{ Sanitation treatment } & \multicolumn{4}{|c|}{ Nonsanitation treatment } \\
\hline & & \multicolumn{2}{|c|}{ Érdi bőtermő } & \multicolumn{2}{|c|}{ Újfehértói fürtös } & \multicolumn{2}{|c|}{ Érdi bőtermő } & \multicolumn{2}{|c|}{ Újfehértói fürtös } \\
\hline & & 2003 & 2004 & 2003 & 2004 & 2003 & 2004 & 2003 & 2004 \\
\hline Untreated & & $12.8 \mathrm{j}$ & $46.6 \mathrm{~m}$ & $7.1 \mathrm{ij}$ & $26.8 \mathrm{i}$ & 16.11 & $54.7 \mathrm{k}$ & $8.4 \mathrm{~g}$ & $32.6 \mathrm{j}$ \\
\hline Conv. & ВBCH 59, 65 & $0.9 \mathrm{a}$ & $3.8 \mathrm{a}$ & $0.0 \mathrm{a}$ & $2.8 \mathrm{a}$ & $1.6 \mathrm{a}$ & $4.6 \mathrm{a}$ & $0.3 \mathrm{a}$ & $3.1 \mathrm{a}$ \\
\hline Co-Hydr.1 & ВBCH 59 & $9.1 \mathrm{fghi}$ & 35.2 hijk & $6.2 \mathrm{hij}$ & $21.2 \mathrm{defg}$ & $10.1 \mathrm{j}$ & $39.2 \mathrm{ghi}$ & $6.6 \mathrm{fg}$ & $24.2 \mathrm{efgh}$ \\
\hline Co-Hydr.2 & ВBCH 65 & $6.3 \mathrm{cdef}$ & 31.9 fghi & $3.9 \mathrm{efg}$ & $19.5 \mathrm{de}$ & $6.5 \mathrm{efg}$ & $38.1 \mathrm{fgh}$ & $4.2 \mathrm{e}^{-}$ & $23.2 \mathrm{defg}$ \\
\hline Co-Hydr.3 & ВBCH 59, 65 & $3.4 \mathrm{abc}$ & $22.3 \mathrm{bcd}$ & $1.2 \mathrm{ab}$ & $14.3 \mathrm{bc}$ & 4.7 bcde & $24.9 \mathrm{bcd}$ & $1.3 \mathrm{ab}$ & $15.9 \mathrm{~b}$ \\
\hline Co-Hydr.4 & ВВСН $59,65,70$ & $3.1 \mathrm{ab}$ & $17.1 \mathrm{~b}$ & $0.9 \mathrm{ab}$ & $13.2 \mathrm{~b}$ & 4.3 bcde & $22.1 \mathrm{~b}$ & $0.9 \mathrm{ab}$ & $15.1 \mathrm{~b}$ \\
\hline Wett-S1 & ВBCH 59 & 10.9 hij & $44.4 \mathrm{~lm}$ & $7.4 \mathrm{j}$ & 25.9 hi & $12.5 \mathrm{k}$ & $48.9 \mathrm{jk}$ & $8.1 \mathrm{~g}$ & $30.7 \mathrm{ij}$ \\
\hline Wett-S2 & ВBCH 65 & 9.8 ghij & $40.6 \mathrm{jklm}$ & $6.7 \mathrm{hij}$ & 25.4 fghi & $9.3 \mathrm{hij}$ & $47.5 \mathrm{ijk}$ & $7.5 \mathrm{fg}$ & $29.2 \mathrm{hij}$ \\
\hline Wett-S3 & ВBCH 59, 65 & 5.4 bcde & 30.3 efghi & $3.2 \mathrm{de}$ & 21.9 defgh & 5.7 efg & $35.4 \mathrm{efgh}$ & $3.4 \mathrm{de}$ & 23.9 defgh \\
\hline Wett-S4 & BBCH $59,65,70$ & $4.4 \mathrm{bcd}$ & 26.2 cdefg & $3.5 \mathrm{de}$ & $20.9 \mathrm{def}$ & 5.5 defg & 32.6 defg & 3.2 cde & $24.1 \mathrm{efgh}$ \\
\hline MWett-S1 & ВBCH 59 & $12.1 \mathrm{ij}$ & $42.6 \mathrm{klm}$ & $6.9 \mathrm{hij}$ & 25.8 ghi & $10.3 \mathrm{jk}$ & $47.1 \mathrm{ijk}$ & $7.5 \mathrm{fg}$ & 28.3 ghij \\
\hline MWett-S2 & BBCH 65 & $8.2 \mathrm{efgh}$ & 36.9 ijkl & $6.9 \mathrm{hij}$ & 24.5 fghi & $9.6 \mathrm{ij}$ & $46.3 \mathrm{ij}$ & $6.1 \mathrm{f}$ & 27.1 fghij \\
\hline MWett-S3 & ВBCH 59, 65 & $4.1 \mathrm{bc}$ & 28.1 defgh & 2.5 bcde & 21.4 defgh & $5.1 \mathrm{cdef}$ & $30.6 \mathrm{cdef}$ & $3.3 \mathrm{cde}$ & $22.4 \mathrm{cdef}$ \\
\hline MWett-S4 & ВВСH $59,65,70$ & $4.3 \mathrm{bc}$ & 24.3 bcdef & 2.3 bcde & $18.2 \mathrm{~cd}$ & $5.4 \mathrm{defg}$ & 27.5 bcde & 3.2 cde & 20.8 bcde \\
\hline Lime-S1 & ВBCH 59 & $9.5 \mathrm{ghi}$ & $37.8 \mathrm{ijkl}$ & $5.3 \mathrm{fgh}$ & 23.3 efghi & $10.7 \mathrm{jk}$ & $40.9 \mathrm{hij}$ & $6.4 \mathrm{f}$ & 26.1 efghi \\
\hline Lime-S2 & ВBCH 65 & 7.4 defg & 35.1 hijk & $3.1 \mathrm{cde}$ & 22.3 defghi & $7.2 \mathrm{fgh}$ & $42.7 \mathrm{hij}$ & $4.1 \mathrm{e}$ & 24.8 efgh \\
\hline Lime-S3 & ВBCH 59, 65 & $3.3 \mathrm{abc}$ & 24.8 bcdef & $1.4 \mathrm{abc}$ & $14.9 \mathrm{bc}$ & $2.9 \mathrm{abc}$ & 27.5 bcde & $2.3 \mathrm{bcd}$ & $18.2 \mathrm{bcd}$ \\
\hline Lime-S4 & ВBCH $59,65,70$ & $3.1 \mathrm{ab}$ & $21.2 \mathrm{bcd}$ & $1.9 \mathrm{bcd}$ & $13.5 \mathrm{~b}$ & $3.4 \mathrm{abcd}$ & $25.6 \mathrm{bcd}$ & $3.2 \mathrm{cde}$ & $16.7 \mathrm{bc}$ \\
\hline Lime-S+MW-S 1 & BBCH 59 & 9.2 fghi & $36.7 \mathrm{ijkl}$ & $5.4 \mathrm{ghi}$ & 21.4 defgh & 9.2 hij & 41.4 hij & $6.2 \mathrm{f}$ & 24.9 efgh \\
\hline Lime-S+MW-S 2 & ВBCH 65 & $6.2 \mathrm{cdef}$ & 33.2 ghij & $3.6 \mathrm{def}$ & 21.9 defgh & $7.4 \mathrm{ghi}$ & 41.6 hij & $4.2 \mathrm{e}$ & 25.3 efghi \\
\hline Lime-S+MW-S 3 & BBCH 59, 65 & $2.4 \mathrm{ab}$ & 24.1 bcde & $1.3 \mathrm{ab}$ & $14.5 \mathrm{bc}$ & $2.9 \mathrm{abc}$ & $26.6 \mathrm{bcd}$ & $1.9 \mathrm{bcd}$ & $16.8 \mathrm{bc}$ \\
\hline Lime-S+MW-S 4 & ВBCH $59,65,70$ & $2.6 \mathrm{ab}$ & $19.8 \mathrm{bc}$ & $1.1 \mathrm{ab}$ & $13.7 \mathrm{bc}$ & $2.7 \mathrm{ab}$ & $23.7 \mathrm{bc}$ & $1.8 \mathrm{abc}$ & $15.1 \mathrm{~b}$ \\
\hline$F$ test $^{2}$ & 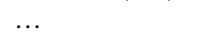 & $* *$ & $* * *$ & $*$ & $* * *$ & *** & $* * *$ & $*$ & *** \\
\hline
\end{tabular}

${ }^{w}$ Brown rot incidence data shown are back-transformed means from arcsine $(\%)^{1 / 2}$ values. Values within columns followed by different letters are significantly different.

${ }^{\mathrm{x}}$ Fungicide treatments: Conv. = conventional fungicide, vinclozoline and penconazol (Ronilan DF and Topas 100 EC, respectively); Co-Hydr. $=$ copper hydroxide (Funguran-OH $50 \mathrm{WP}$ ); Wett-S = nonmicronized wettable sulfur (Kumulus S); MWett-S = micronized wettable sulfur (Microthiol Special); Lime-S = lime sulfur (Tiosol); Lime-S+MW-S = lime sulfur in combination with micronized wettable sulfur (Tiosol + Microthiol Special).

y Application timing: $\mathrm{BBCH} 59=$ closed blossom, $\mathrm{BBCH} 65=$ full bloom, and $\mathrm{BBCH} 70=$ petal fall according to $\mathrm{BBCH}$ growth stage scale for stone fruit (32).

${ }^{z} F$ test: *,**, and $* * *$ significant at $P \leq 0.05,0.01$, and 0.001 , respectively. Because of the back transformation on brown rot incidence data, no least significant difference $e_{0.05}$ (LSD0.05) and standard error of difference (SED) values are available. 
compared with nonsanitized plots; however, the differences were significant only in $2004\left(P<0.05\right.$ and $\operatorname{LSD}_{0.05}=7.61$ for cv. Érdi bötermö; $P<0.05$ and $\operatorname{LSD}_{0.05}=$ 5.47 for cv. Újfehértói fürtös). In each experimental year, blossom blight incidence was significantly higher $(P<0.05)$ in cv. Érdi bötermö compared with cv. Újfehértói fürtös (Table 3; statistical analyses not shown).

Phytotoxicity. Analyses of variance on phytotoxicity values indicated significant differences $(P<0.05)$ between years, cultivars, and the 22 fungicide treatments; however, no significant effect was found for the sanitation treatment (Table 2). Therefore, in contrast to blossom blight incidence data, the phytotoxicity data were averaged for the two sanitation treatments and not shown separately for both cultivars and years (Table 4). The conventional and wettable sulfur treatments did not cause less damage on spur-leaf clusters $(P<$ $0.05)$ compared with most treatments of copper hydroxide or lime sulfur. In both years and cultivars, treatments of copper hydroxide and lime sulfur negatively af- fected spur-leaf clusters in all treatments where fungicides were applied at full bloom stage (BBCH 65). For these treatments, phytotoxicity data were higher in 2004 than in 2003. In 2004, damage on spur-leaf clusters was significantly higher in lime sulfur treatments applied three times with or without wettable sulfur on cv. Érdi bötermö compared with similar treatments in $2003\left(P<0.05\right.$ and $\mathrm{LSD}_{0.05}=$ 1.19 for Lime-S4; $P<0.05$ and $\mathrm{LSD}_{0.05}=$ 1.26 for Lime-S+MWett-S4).

Fruit yield. Analyses of variance on yield data indicated significant differences $(P<0.05)$ between years, cultivars, and the 22 fungicide treatments; however, no significant effects were found for sanitation treatments (Table 2). There were significant year-cultivar interactions but this was not as dominating as the main effect of cultivar. Therefore, as with phytotoxicity data, yield data were shown separately for years and cultivars only (Table 5). Fungicide treatments had no or little effect on the yield of cvs. Érdi bötermö and Újfehértói fürtös in 2003 (Table 5). However, in 2004, two or three applications of cop-

Table 4. Influence of fungicide treatments on phytotoxicity on sour cherry cvs. Érdi bőtermő and Úfehértói fürtös in a sour cherry orchard (Eperjeske, Hungary, 2003 and 2004) ${ }^{\mathrm{w}}$

\begin{tabular}{|c|c|c|c|c|c|}
\hline \multirow[b]{2}{*}{ Treatments $^{x}$} & \multirow[b]{2}{*}{ Application timingy } & \multicolumn{2}{|c|}{ Érdi bőtermő } & \multicolumn{2}{|c|}{ Újfehértói fürtös } \\
\hline & & 2003 & 2004 & 2003 & 2004 \\
\hline Untreated & $\ldots$ & $0.2 \mathrm{a}$ & $0.2 \mathrm{a}$ & $0.2 \mathrm{a}$ & $0.2 \mathrm{a}$ \\
\hline Conv. & ВBCH 59, 65 & $0.3 \mathrm{a}$ & $0.4 \mathrm{a}$ & $0.3 \mathrm{a}$ & $0.3 \mathrm{a}$ \\
\hline Co-Hydr.1 & ВBCH 59 & $0.9 \mathrm{a}$ & $1.6 \mathrm{~b}$ & $1.0 \mathrm{a}$ & $1.3 \mathrm{~b}$ \\
\hline Co-Hydr.2 & ВBCH 65 & $2.5 \mathrm{~b}$ & $3.4 \mathrm{c}$ & $2.1 \mathrm{~b}$ & $2.6 \mathrm{c}$ \\
\hline Co-Hydr.3 & ВВСН 59, 65 & $2.9 \mathrm{~b}$ & $3.5 \mathrm{c}$ & $2.6 \mathrm{~b}$ & $2.8 \mathrm{c}$ \\
\hline Co-Hydr.4 & ВВСН 59, 65, 70 & $2.9 \mathrm{~b}$ & $3.5 \mathrm{c}$ & $2.5 \mathrm{~b}$ & $3.1 \mathrm{c}$ \\
\hline Wett-S1 & ВBCH 59 & $0.3 \mathrm{a}$ & $0.4 \mathrm{a}$ & $0.3 \mathrm{a}$ & $0.4 \mathrm{ab}$ \\
\hline Wett-S2 & ВBCH 65 & $0.6 \mathrm{a}$ & $0.6 \mathrm{ab}$ & $0.5 \mathrm{a}$ & $0.5 \mathrm{ab}$ \\
\hline Wett-S3 & ВBCH 59, 65 & $0.5 \mathrm{a}$ & $0.7 \mathrm{ab}$ & $0.6 \mathrm{a}$ & $0.6 \mathrm{ab}$ \\
\hline Wett-S4 & ВBCH 59, 65, 70 & $0.5 \mathrm{a}$ & $0.5 \mathrm{ab}$ & $0.7 \mathrm{a}$ & $0.7 \mathrm{ab}$ \\
\hline MWett-S1 & BBCH 59 & $0.3 \mathrm{a}$ & $0.4 \mathrm{a}$ & $0.3 \mathrm{a}$ & $0.4 \mathrm{ab}$ \\
\hline MWett-S2 & ВBCH 65 & $0.7 \mathrm{a}$ & $0.6 \mathrm{ab}$ & $0.5 \mathrm{a}$ & $0.5 \mathrm{ab}$ \\
\hline MWett-S3 & ВBCH 59, 65 & $0.7 \mathrm{a}$ & $0.5 \mathrm{ab}$ & $0.5 \mathrm{a}$ & $0.6 \mathrm{ab}$ \\
\hline MWett-S4 & ВВСН $59,65,70$ & $0.5 \mathrm{a}$ & $0.5 \mathrm{ab}$ & $0.5 \mathrm{a}$ & $0.6 \mathrm{ab}$ \\
\hline Lime-S1 & $\ldots$ & $0.9 \mathrm{a}$ & $1.3 \mathrm{ab}$ & $0.9 \mathrm{a}$ & $1.3 \mathrm{~b}$ \\
\hline Lime-S2 & ВBCH 65 & $2.4 \mathrm{~b}$ & $3.3 \mathrm{c}$ & $2.0 \mathrm{~b}$ & $2.6 \mathrm{c}$ \\
\hline Lime-S3 & ВВСН 59, 65 & $2.3 \mathrm{~b}$ & $3.2 \mathrm{c}$ & $2.0 \mathrm{~b}$ & $2.7 \mathrm{c}$ \\
\hline Lime-S4 & ВВСН 59, 65, 70 & $2.2 \mathrm{~b}$ & $3.4 \mathrm{c}$ & $2.1 \mathrm{~b}$ & $3.1 \mathrm{c}$ \\
\hline Lime-S+MWett-S 1 & ВBCH 59 & $0.9 \mathrm{a}$ & $1.3 \mathrm{ab}$ & $0.9 \mathrm{a}$ & $1.4 \mathrm{~b}$ \\
\hline Lime-S+MWett-S 2 & ВBCH 65 & $2.2 \mathrm{~b}$ & $3.2 \mathrm{c}$ & $2.0 \mathrm{~b}$ & $2.5 \mathrm{c}$ \\
\hline Lime-S+MWett-S 3 & ВBCH 59, 65 & $2.2 \mathrm{~b}$ & $3.2 \mathrm{c}$ & $2.4 \mathrm{~b}$ & $2.8 \mathrm{c}$ \\
\hline Lime-S+MWett-S 4 & ВВСН 59, 65, 70 & $2.2 \mathrm{~b}$ & $3.5 \mathrm{c}$ & $2.2 \mathrm{~b}$ & $3.2 \mathrm{c}$ \\
\hline$F$ test $^{\mathrm{z}}$ & $\ldots$ & $* * *$ & $* * *$ & $* *$ & $* * *$ \\
\hline
\end{tabular}

w Phytotoxicity assessments were rated according to the scale where $0=$ no damage; $1=$ cluster size 60 to $80 \%$ of normal size, no necroses on cluster; $2=$ cluster size less than $60 \%$ of normal size, no necroses on cluster; $3=$ cluster size less than $60 \%$ of normal size and necroses on cluster less than $3 \% ; 4=$ cluster size less than $60 \%$ of normal size and 3 to $6 \%$ cluster necroses; and $5=$ cluster size less than $60 \%$ of normal size and necroses on cluster more than $6 \%$. Phytotoxicity data shown are back-transformed means from arcsine $(\%)^{1 / 2}$ values. Values within columns followed by different letters are significantly different.

${ }^{\mathrm{x}}$ Fungicide treatments: Conv. $=$ conventional fungicide, vinclozoline and penconazol (Ronilan DF and Topas 100 EC, respectively); Co-Hydr. = copper hydroxide (Funguran-OH $50 \mathrm{WP}$ ); Wett-S = nonmicronized wettable sulfur (Kumulus S); MWett-S = micronized wettable sulfur (Microthiol Special); Lime-S = lime sulfur (Tiosol); Lime-S+MWett-S = lime sulfur in combination with micronized wettable sulfur (Tiosol + Microthiol Special).

y Application timing: $\mathrm{BBCH} 59=$ closed blossom, $\mathrm{BBCH} 65=$ full bloom, and $\mathrm{BBCH} 70=$ petal fall according to $\mathrm{BBCH}$ growth stage scale for stone fruit (32).

${ }^{\mathrm{z}} F$ test: *,**, and $* * *$ significant at $P \leq 0.05,0.01$, and 0.001 , respectively. Because of the backtransformation on phytotoxicity data, no least significant difference ${ }_{0.05}$ (LSD0.05) and standard error of difference (SED) values are available. per hydroxide or lime sulfur during the bloom period resulted in significantly higher yield $(P<0.05)$ in both cultivars compared with untreated plots.

\section{DISCUSSION}

None of the inorganic fungicide treatments were as effective as the conventional fungicide treatment; however, copper hydroxide and lime sulfur in combination with sanitation practices significantly reduced blossom blight when applied two or three times during bloom. Although these treatments caused some phytotoxicity, they significantly increased crop yield in a year with severe $M$. laxa infections compared with the untreated controls.

Earlier studies showed curative (20 to 72 $\mathrm{h}$ after infection) in addition to protective activity of lime sulfur, whereas copperbased products were reported to have only protective activity $(18,22,33,34,52)$. Our experience in organic sour cherry orchards showed that the curative activity of lime sulfur may exceed 20 to $35 \mathrm{~h}$ during the bloom period for blossom blight control (I. J. Holb and F. Abonyi, unpublished). This additional curative activity of lime sulfur may give a significant advantage over copper-based products in practice. However, in this study, the efficacy and phytotoxicity of lime sulfur treatments were not significantly different from copper hydroxide treatments.

The curative activity of lime sulfur is dependent on the availability of moisture $(12,16,52,53)$; however, increasing leaf wetness or relative humidity also can enhance the phytotoxic effects of lime sulfur $(6,11,22,46,51,52)$. This is consistent with our study, where three applications of lime sulfur during bloom in a wet year resulted in increased phytotoxic effects compared with a dry year. The addition of a lower dose of wettable sulfur has been recommended to reduce phytotoxicity on apple blossoms (23); however, in this study, the phytotoxicity of lime sulfur alone did not differ significantly from the treatment of lime sulfur in combination with wettable sulfur.

This study agrees with previous research demonstrating that wettable sulfur cannot control blossom blight effectively when disease pressure is high $(10,58)$. Additionally, micronized wettable sulfur did not perform better than regular wettable sulfur in this study. This is in contrast to earlier work showing good results with micronized wettable sulfur for peach scab control $(43,58)$. Furthermore, the combination of lime sulfur and wettable sulfur did not result in enhanced blossom blight control. Consequently, we were not able to document a benefit from the addition of wettable sulfur to lime sulfur in regard to phytotoxicity or fungicidal efficacy.

Inorganic fungicide treatments for blossom blight control were effective only if applied more than once during bloom. 
Single applications failed to control blossom blight, especially in a wet year with high disease pressure. Earlier studies recommended three applications of elemental sulfur in 7-day intervals for blossom blight management during the flowering period in organic sweet cherry, peach, and apricot production $(1,31,48)$. Our study is in agreement with this recommendation; however, in organic sour cherry production, elemental sulfur might be replaced with the more effective lime sulfur.

Sanitation (removal of blighted twigs and mummified fruit) reduced blossom blight in both cultivars in 2004. This is consistent with earlier studies stating that removal of mummified fruit and blighted twigs during the dormant season can considerably decrease disease $(9,28,57)$. Moreover, Tamm et al. (49) demonstrated that complete sanitation substantially decreases the primary inoculum and the subsequent disease epidemic. In this study, the influence of sanitation on disease incidence was significant only in 2004. The low disease pressure in 2003 may have been responsible for the lack of significant differences between sanitation treatments.

Significant differences in blossom blight damage were found between the two sour cherry cultivars. The higher susceptibility of cv. Érdi bötermö may be explained by significantly more rain and lower temperatures during the bloom period of cv. Érdi bötermö compared with cv. Újfehértói fürtös in both years. These results are consistent with earlier reports describing $\mathrm{cv}$. Érdi bőtermő as more susceptible to blossom blight than cv. Újfehértói fürtös (44). The cultivar differences were significantly larger in 2004 compared with 2003, most likely because the bloom period in cv. Érdi bőtermö was longer during cold and rainy weather in 2004, resulting in longer exposure to Monilinia spp. infection. These findings suggest that sour cherry cultivars with later and shorter blooming periods will experience less blossom blight pressure and, therefore, may be more suitable for organic production.

The reduced fruit yield in 2004 in untreated plots indicated that insufficient disease control during the bloom period will impact yield negatively in wet years with high disease pressure. Hamilton $(18,19)$ stated that lime sulfur injured flowers and leaves of apples, resulting in reduced crop yield. However, Holb and Heijne (23) and Holb et al. (22), in agreement with the present study, showed that copper hydroxide and lime sulfur did not decrease apple fruit yield significantly

Table 5. Influence of fungicide treatments on fruit yield of sour cherry cvs. Érdi bőtermő and Újfehértói fürtös (Eperjeske, Hungary, 2003 and 2004) ${ }^{\mathrm{w}}$

\begin{tabular}{|c|c|c|c|c|c|}
\hline \multirow[b]{2}{*}{ Treatments $^{\mathrm{x}}$} & \multirow[b]{2}{*}{ Application timing ${ }^{y}$} & \multicolumn{2}{|c|}{ Érdi bőtermő } & \multicolumn{2}{|c|}{ Újfehértói fürtös } \\
\hline & & 2003 & 2004 & 2003 & 2004 \\
\hline Untreated & & $11.4 \mathrm{a}$ & $7.5 \mathrm{a}$ & 12.8 & $8.6 \mathrm{a}$ \\
\hline Conv. & ВBCH 59, 65 & $13.3 \mathrm{~b}$ & $12.4 \mathrm{f}$ & 14.2 & $12.3 \mathrm{f}$ \\
\hline Co-Hydr.1 & BBCH 59 & $11.5 \mathrm{a}$ & $8.3 \mathrm{ab}$ & 12.3 & $9.2 \mathrm{ab}$ \\
\hline Co-Hydr.2 & ВBCH 65 & $12.1 \mathrm{a}$ & $9.3 \mathrm{bcd}$ & 12.6 & $9.6 \mathrm{abcd}$ \\
\hline Co-Hydr.3 & BBCH 59, 65 & $12.0 \mathrm{a}$ & $10.6 \mathrm{de}$ & 12.9 & 11.4 ef \\
\hline Co-Hydr.4 & ВBCH $59,65,70$ & $12.2 \mathrm{a}$ & $11.4 \mathrm{ef}$ & 12.9 & $11.6 \mathrm{ef}$ \\
\hline Wett-S1 & BBCH 59 & $11.3 \mathrm{a}$ & $8.1 \mathrm{ab}$ & 12.5 & $9.3 \mathrm{abc}$ \\
\hline Wett-S2 & BBCH 65 & $12.1 \mathrm{a}$ & $10.2 \mathrm{cde}$ & 12.8 & $9.1 \mathrm{ab}$ \\
\hline Wett-S3 & ВBCH 59, 65 & $11.8 \mathrm{a}$ & $8.6 \mathrm{ab}$ & 12.7 & $9.4 \mathrm{abc}$ \\
\hline Wett-S4 & BBCH $59,65,70$ & $11.9 \mathrm{a}$ & $8.1 \mathrm{ab}$ & 12.2 & $9.1 \mathrm{ab}$ \\
\hline MWett-S1 & ВBCH 59 & $11.5 \mathrm{a}$ & $8.1 \mathrm{ab}$ & 13.3 & $9.4 a b c$ \\
\hline MWett-S2 & BBCH 65 & $11.8 \mathrm{a}$ & $8.9 \mathrm{bc}$ & 12.5 & $10.9 \mathrm{def}$ \\
\hline MWett-S3 & ВBCH 59, 65 & $12.1 \mathrm{a}$ & $8.3 \mathrm{ab}$ & 13.2 & $9.2 \mathrm{ab}$ \\
\hline MWett-S4 & ВВСН $59,65,70$ & $11.7 \mathrm{a}$ & $8.3 \mathrm{ab}$ & 13.4 & $9.3 \mathrm{abc}$ \\
\hline Lime-S1 & ВBCH 59 & $11.5 \mathrm{a}$ & $8.6 a b$ & 12.7 & $9.2 \mathrm{ab}$ \\
\hline Lime-S2 & ВBCH 65 & $11.2 \mathrm{a}$ & $8.9 \mathrm{bc}$ & 12.5 & 10.3 bcde \\
\hline Lime-S3 & BBCH 59, 65 & $12.1 \mathrm{a}$ & $10.5 \mathrm{de}$ & 13.2 & $11.3 \mathrm{ef}$ \\
\hline Lime-S4 & ВВСН $59,65,70$ & $12.0 \mathrm{a}$ & $11.5 \mathrm{ef}$ & 13.1 & 11.6 ef \\
\hline Lime-S+MWett-S 1 & BBCH 59 & $11.9 \mathrm{a}$ & $8.9 \mathrm{bc}$ & 13.4 & $9.3 \mathrm{abc}$ \\
\hline Lime-S+MWett-S 2 & ВBCH 65 & $11.8 \mathrm{a}$ & $9.3 \mathrm{bcd}$ & 12.9 & $10.7 \mathrm{cde}$ \\
\hline Lime-S+MWett-S 3 & BBCH 59, 65 & $11.9 \mathrm{a}$ & $10.6 \mathrm{de}$ & 12.5 & $11.5 \mathrm{ef}$ \\
\hline Lime-S+MWett-S 4 & $\mathrm{BBCH} 59,65,70$ & $12.2 \mathrm{a}$ & $11.2 \mathrm{ef}$ & 13.1 & $11.1 \mathrm{ef}$ \\
\hline$F$ test $^{\mathrm{z}}$ & $\ldots$ & $*$ & $* * *$ & NS & *** \\
\hline $\operatorname{SED}(\mathrm{df}=105)$ & $\ldots$ & 0.74 & 0.67 & $\ldots$ & 0.71 \\
\hline $\mathrm{LSD}_{0.05}$ & $\ldots$ & 1.51 & 1.35 & $\ldots$ & 1.40 \\
\hline
\end{tabular}

${ }^{w}$ Yield data shown are back-transformed means from arcsine $(\%)^{1 / 2}$ values and represent kilograms per tree. Values within columns followed by different letters are significantly different.

${ }^{\mathrm{x}}$ Fungicide treatments: Conv. $=$ conventional fungicide, vinclozoline and penconazol (Ronilan DF and Topas 100 EC, respectively); Co-Hydr. = copper hydroxide (Funguran-OH $50 \mathrm{WP}$ ); Wett-S = nonmicronized wettable sulfur (Kumulus S); MWett-S = micronized wettable sulfur (Microthiol Special); Lime-S = lime sulfur (Tiosol); Lime-S+MWett-S = lime sulfur in combination with micronized wettable sulfur (Tiosol + Microthiol Special); SED = standard error of difference; $\mathrm{df}=$ degrees of freedom; $\mathrm{LSD}=$ least significant difference.

${ }^{\mathrm{y}}$ Application timing: $\mathrm{BBCH} 59=$ closed blossom, $\mathrm{BBCH} 65=$ full bloom, and $\mathrm{BBCH} 70=$ petal fall according to $\mathrm{BBCH}$ growth stage scale for stone fruit (32).

${ }^{2} F$ test: *,**, and ${ }^{* * *}$ significant at $P \leq 0.05,0.01$, and 0.001 , respectively; NS $=$ not significant. compared with wettable sulfur or untreated plots despite causing some phytotoxicity. In fact, in this study, sour cherry fruit yield was higher in 2004 in copper hydroxide and lime sulfur treatments applied two or three times compared with untreated plots.

In summary, lime sulfur may be able to replace copper-based products in organic sour cherry production without compromising blossom blight control or yield. However, both compounds may provide insufficient control of blossom blight in wet years, even when combined with sanitation practices. Other sulfur-based products, such as micronized or nonmicronized wettable sulfur, are even less efficacious and may not adequately prevent blossom blight when disease pressure is low or medium. The results imply that an integrated control strategy is needed for blossom blight control in organic sour cherry production. Other control methods (e.g., effective biocontrol agents, inducers of systemic acquired resistance, and so on) in combination with sanitation, cultivar selection, or fungicide applications may provide more adequate blossom blight control in organic sour cherry production.

\section{ACKNOWLEDGMENTS}

We thank A. F. Fieldsend (University of Debrecen, Centre of Agricultural Sciences) and J. M. Gall (University of Debrecen, Institute of Mathematics and Informatics) for their critical reading of the manuscript and valuable suggestions, and F. Abonyi and F. Abonyi, Jr. (Abonyi Ltd., Eperjeske) for their excellent cooperation in treatment set-up and field assessments.

\section{LITERATURE CITED}

1. Ames, G. K. 2000. Organic and Low-Spray Peach Production. Appropriate Technology Transfer for Rural Areas, Fayetteville, AR.

2. Anonymous. 1991. Environmental Quality Standards for Soils and Water. Netherlands Ministry of Housing, Physical Planning and Environment, Den Haag, The Netherlands.

3. Anonymous. 1997. Standards for Organic Production. Association for Hungarian Organic Production, Budapest, Hungary. (In Hungarian)

4. Anonymous. 1997. Guideline for the efficacy evaluation of plant products: Phytotoxicity assessment. Eur. Mediterr. Plant Prot. Org. 135:31-36.

5. Anonymous. 1998. Guideline for the efficacy evaluation of fungicides: Monilinia laxa. OEPP/EPPO Bull. 28:291-295.

6. Atkinson, J. D., Brien, R. M., Chamberlain, E. E., Cottier, W., Dingley, J. M., Jacks, H., Ried, W. D., and Taylor, G. G. 1956. Plant Protection in New Zealand. Government Printer, Wellington, New Zealand.

7. Batra, L. R. 1991. World species of Monilinia (Fungi): Their ecology, biosystematics and control. Mycologia Memoir, No. 16. J. Cramer, Berlin, Germany.

8. Berend, I. 1957. New methods for controlling brown rot on sour cherry. A növényvédelem időszerü kérdései 2:42-46. (In Hungarian)

9. Byrde, R. J. W., and Willetts, H. J. 1977. The Brown Rot Fungi of Fruit. Their Biology and Control. Pergamon Press, Oxford.

10. Chandler, W. A. 1974. Control of peach disease with benomyl in full and modified schedules. HortScience 9:332-333.

11. Cunningham, G. H. 1935. Plant Protection by the Aid of Therapeutants. John McIndoe Printer, Duendin, New Zealand. 
12. Doran, A. 1922. Laboratory studies of the toxicity of some sulphur fungicides. N. H. Agric. Exp. Stn. Tech. Bull. 19:1-11.

13. Ellis, M. A., Ferree, D. C., and Madden, L. V. 1998. Effects of an apple scab-resistant cultivar on use patterns of inorganic and organic fungicides and economics of disease control. Plant Dis. 82:428-433.

14. Flores-Veles, L. M., Ducaroir, J., Jaunet, A. M., and Robert, M. 1996. Study of the distribution of copper in an acid sandy vineyard soil by three different methods. Eur. J. Soil Sci. 47:523-532.

15. Friis, K., Damgaard, C., and Holmstrup, M. 2004. Sublethal soil copper increase mortality in the earthworm Aporrectodea caliginosa during drought. Ecotox. Environ. Safe. 57:65-73.

16. Goldsworthy, M. C. 1928. The fungicidal action of liquid lime sulphur. Phytopathology 18:355-360.

17. Gomez, K. A., and Gomez, A. A. 1984. Statistical Procedures for Agricultural Research. John Wiley \& Sons, New York.

18. Hamilton, J. M. 1931. Studies of fungicidal action of certain dust and sprays in the control of apple scab. Phytopathology 21:445-523.

19. Hamilton, J. M. 1932. Recent investigations on the control of apple scab in the Hudson Valley. N. Y. State Agric. Exp. Stn. Tech. Bull. 604:44.

20. Holb, I. J. 2003. The brown rot fungi of fruit crops (Monilinia spp.). I. Important features of their biology. Int. J. Hortic. Sci. 9(3-4):23-36.

21. Holb, I. J. 2004. The brown rot fungi of fruit crops (Monilinia spp.). III. Important features of their disease control. Int. J. Hortic. Sci. 10(4):31-48

22. Holb, I. J., de Jong, P. F., and Heijne, B. 2003. Efficacy and phytotoxicity of lime sulphur in organic apple production. Ann. Appl. Biol. 142:225-233.

23. Holb, I. J., and Heijne, B. 2001. Evaluating primary scab control in organic apple production. Gartenbauwissenschaft 66:254-261.

24. Holmstrup, M., Petersen, B., and Larsen, M. 1998. Combined effects of copper, desiccation, and frost on the viability of earthworm cocoons. Environ. Toxicol. Chem. 17:897-901

25. IFOAM, 1989. Basic Standards for Organic Agriculture. Tholey-Theley Press, New York.

26. IFOAM, 1998. Basic Standards for Organic Production and Processing. Tholey-Theley Press, New York.

27. IFOAM, 2000. IFOAM Basic Standards for Organic Production and Processing. TholeyTheley Press, New York.

28. Kennel, W. 1968. Physikalische Bekämpfung von Obstbaum-Krankheiten als Kulturma name. J. Plant Dis. Prot. 75:585-591.

29. Lewis, F. H., and Hickey, K. D. 1972. Fungicide usage on deciduous fruit trees. Annu. Rev. Phytopathol. 10:399-428.

30. McCallan, S. E. A. 1967. History of fungi- cides. Pages 1-37 in: Fungicides: An Advanced Treatise 1. D. C. Torgeson, ed. Academic Press, New York.

31. McLaren, G. F., and Fraser, J. A. 2000. Control of brown rot (Monilinia fructicola) on organic apricots. N. Z. Plant Prot. 53:7-12.

32. Meier, U., Graf, H., Hack, H., Hess, M., Kennel, W., Klose, R., Mappes, D., Seipp, D., Stauss, R., Streif, J., and van den Boom, T. 1994. Phänologische Entwicklungsstadien des Kernobstes (Malus domestica Borkh. und Pyrus communis L.) des Steinobstes (PrunusArten), der Johannisbeere (Ribes-Arten) und der Erdbeere (Fragaria $\times$ ananassa Duch.) Codierung und Beschreibung nach der erweiterten BBCH-Skala, mit Abbildungen. Nachrichtenbl. Dtsch. Pflanzenschutzdienst (Berlin) 46 (7):141-153.

33. Mills, W. D. 1944. Efficient use of sulfur dusts and sprays during rain to control apple scab. Cornell Univ. Bull. 630:1-4.

34. Mills, W. D. 1947. Effects of sprays of lime sulfur and of elemental sulfur on apple in relation to yield. Cornell Univ. Agric. Exp. Stn. 273:38.

35. Nyéki, J., Szabó, Z., Soltész, M. 2003. Sour cherry (Prunus cerasus L.). Pages 359-382 in: Floral Biology, Pollination and Fertlisation in Temperate Zone Fruit Species and Grape. P. Kozma, J. Nyéki, M. Soltész, and Z. Szabó, eds. Akadémia Kiadó, Budapest, Hungary.

36. Ogawa, J. M., Manji, B. T., and Sonoda, R. M. 1985. Management of the brown rot disease on stone fruits and almonds in California. N. Y. State Agric. Exp. Stn. Geneva Specific Rep. 55:8-15.

37. Osorio, J. M., Adaskaveg, J. E., and Ogawa, J. M. 1994. Inhibition of mycelial growth of Monilinia species and suppression and control of brown rot blossom blight of almond with iprodione and E-0858. Plant Dis. 78:712-716.

38. Paoletti, M. G., Sommaggio, D., Favretto, M. R., Petruzzelli, G., Pezzarossa, B., and Barbafieri, M. 1998. Earthworms as useful bioindicators of agrosystem sustainability in orchards and vineyards with different inputs. Appl. Soil Ecol. 10:137-150.

39. Reganold, J. P., Glover, J. D., Andrews, P. K., and Hinman, H. R. 2001. Sustainability of three apple production systems. Nature (London) 410:926-930

40. Richardson, H. W. 1997. Copper fungicides/bactericides. Pages 93-122 in: Handbook of Copper Compounds and Applications H. W. Richardson, ed. Marcel Dekker, New York.

41. Ritchie, D., and Pollard, D. W. 2003. Evaluation of two dry sulfur formulations for control of peach scab, 2002. Fungic. Nematicide Tests 58:STF015

42. Rudolph, B. A. 1925. Monilinia blossom blight (brown-rot) of apricots. Calif. Univ. Agric.
Exp. Stn. Bull. 383:1-24.

43. Schnabel, G., and Layne, D. R. 2004. Comparison of reduced-application and sulfurbased fungicide programs on scab intensity, fruit quality, and cost of disease control on peach Plant Dis. 88:162-166.

44. Soltész, M. 1997. Resistance to pest and diseases. Pages 71-84 in: Integrated Fruit Produc tion. M. Soltész, ed. Mezőgazda Kiadó, Budapest, Hungary. (In Hungarian)

45. Soltész, M. 1997. Sour cherry. Pages 620-638 in: Integrated Fruit Production. M. Soltész, ed. Mezőgazda Kiadó, Budapest, Hungary. (In Hungarian)

46. Subhash, C. V. 1988. Nontarget Effects of Agricultural Fungicides. CRC Press, London.

47. Tamm, L. 1994. Epidemiological aspects of sweet cherry blossom blight caused by Monilinia laxa. PhD thesis, University of Basel, Schönenbuch, Switzerland.

48. Tamm, L. 1995. Regulierung der Blüten- und Fruchtmonilia bei Süßkirschen. Pages 9-10 in 7. Internationaler Erfahrungsaustausch über Forschungsergebnisse zum Ökologischen Obstbau. K. Fichner, J. Kienzle, M. Straub, and C. Schulz, eds. FÖKO, Weinsberg, Germany.

49. Tamm, L, Häseli, J., Fuchs, J. G., Weibel, F. P. and Wyss, E. 2004. Organic fruit production in humid climates of Europe: bottlenecks and new approaches in disease and pest control Acta Hortic. 638:333-339.

50. Tamm, L., Minder, C. E, and Flückinger, W. 1995. Phenological analyses of brown rot blossom blight of sweet cherry caused by Monilinia laxa. Phytopathology 85:401-408.

51. Tate, K. G., Manktelow, D. W., Walker, J. T. and Stiefel, H. 2000. Disease management in Hawke's Bay apple orchards converting to organic production. N, Z. Plant Prot. 53:1-6.

52. Trapman, M. 2001. Schurft curatief weren met kalkzwavel. Fruittelt 91(3):10-11.

53. Tweedy, B. G. 1981. Inorganic sulphur as a fungicide. Residue Rev. 78:43-68.

54. Van Leeuwen, G. C. M., Holb, I. J., and Jeger, M. J. 2002. Factors affecting mummification and sporulation of pome fruit infected by Monilinia fructigena in Dutch orchards. Plant Pathol. 53:787-793.

55. Van Rhee, J. A. 1976. Effects of soil pollution on earthworms. Pedobiologia 17:201-208.

56. Williams, J. S., and Cooper, R. M. 2004. The oldest fungicide and newest phytoalexin-a reappraisal of the fungitoxicity of elemental sulphur. Plant Pathol. 53:263-279.

57. Wormald, H. 1954. The brown rot disease of fruit trees. Ministry of Agriculture, Fisheries and Food, Tech. Bull. No. 3, Interscience Publishers, London.

58. Zehr, E. I., Miller, R. W., and Gorsuch, C. S. 1984. Reduced use of fungicides and insecticides on peaches. Peach Times 4:6-14 